\title{
Perancangan Aplikasi Steganografi Berbasis Android dengan Metode Pixel Value Differencing (PVD)
}

\author{
Estu Sinduningrum, Anton Supriyanto \\ Fakultas Teknik Program Studi Informatika \\ Universitas Muhammadiyah Prof. Dr. Hamka \\ Jl. Tanah Merdeka no.6, Kp. Rambutan, Ps. Rebo, Jakarta Timur \\ etus2@yahoo.com, anton supriyanto@outlook.co.id
}

Diterima: 13 September 2016. Disetujui: 27 Oktober 2016. Dipublikasikan: Nopember 2016

\begin{abstract}
Simplicity in message exchanges on current technological developments. But on the other hand it brings new problems in terms of security of the message. One method used to overcome this problem is steganography. Steganography is a technique for hiding information on an image. The purpose of this study is to analyze the quality of the images used steganography to hide text messages. One of steganography techniques to be used in this research is Pixel Value Differencing (PVD). Quality of the image of will be dedined. The application will be tested using .bmp, .png and .jpg images types and quality of steganography image is tested by calculating the Mean Square Error (MSE) and Peak Signal to Noise Ratio (PSNR) results of the insertion process of the message. The results of the study showed that the characteristics of the image greatly affect the capacity of the message and the quality of the image after embedded message. Images with different sizes and types tested using MSE get values between $1.62022 \mathrm{~dB}$ and $0.000116 \mathrm{~dB}$ and using PSNR get values between $46.0 \mathrm{~dB}$ and $90.0 \mathrm{~dB}$. This shows that the qualities between the original images and the steganography images are not much different. It can be concluded that the quality of the image are slightly different.
\end{abstract}

Keywords: steganography, pixel value differencing, mse, psnr

\section{I.}

\section{PENDAHULUAN}

Teknologi

dimaksudkan

untuk memudahkan segala bentuk kegiatan kita seharihari. Saat ini perkembangan teknologi yang semakin meningkat dari handphone me mberikan dampak bes ar terhadap penggunaannya[1].

Salah satu sistem operasi yang digunakan oleh smartphone adalah Android. Kelebihan Android dibanding sistem operasi smartphone lainnya karena Android bersifat open source sehingga memudahkan para pengembang untuk menciptakan dan memodifikasi aplikasi atau fiturfitur yang belum ada di sistem Android sesuai dengan keinginan mereka sendiri.
Berbagai macam teknik digunakan untuk melindungi pesan yang dirahasiakan dari orang yang tidak berhak dengan salah satu teknik ini yaitu Steganography, teknik penyembunyian pesan pada media digital[2].

Steganografi dapat menye mbunyikan pesan di berbagai media digital, yaitu gambar, suara dan video atau dalam format lainnya. Beberapa metode telah dikembangkan untuk steganografi diantaranya Least Significant Bits (LSB), Pixel Value Differencing (PVD), Discrete Cosine Transform (DCT), Discrete Wavelet Transform (DWT) [3]. Pada penelitian Least Significant Bits $(L S B)$ metode ini banyak dilakukan dengan pendekatan yang sederhana menyisipkan suatu informasi pada suatu media dengan mengganti nilai-nilai bit dengan bit data yang ingin disisipkan. Namun teknik ini memiliki kelemahan jika sebuah pesan yang akan disisipkan jumlahnya besar maka hasil dari media yang telah disisipkan akan mengalami distorsi besar.

Salah satu metode algoritma yang akan digunakan pada penelitian ini adalah Pixel Value Differencing $(P V D)$ dikarenakan metode ini dike mbangkan untuk men ingkatkan daya tampung pesan dan pengurangan tingkat distorsi pada steganografi[4]. Cara kerja teknik Pixel Value Differencing $(P V D)$ adalah dengan cara membagi media yang akan disisipkan menjadi blok-blok piksel yang bertetangga[5]. Blok-blok tersebut terdiri dari dua buah pixel yang posisinya berdekatan[6]. Bit-bit pesan yang akan disisipkan dihitung dengan besarnya kedua piksel tersebut.

Berdasarkan kelebihan sistem operasi Android dan metode Pixel Value Differencing $(P V D)$, maka dalam penelitian ini akan dibuat Perancangan Aplikasi Steganografi Berbasis Android Dengan Metode Pixel Value Differencing $(P V D)$ untuk proses penyisipan pesan dan ekstraksi pesan [7]. 


\section{LANDASAN TEORI}

\section{A. Citra Digital}

Citra (image) adalah gambar pada bidang dua dimensi. Ditinjau dari sudut pandang matematis, citra merupakan fungsi menerus (continue) dari intensitas cahaya pada bidang dua dimensi. Sumber cahaya menerangi objek, objek memantulkan kembali sebagian dari berkas cahaya tersebut[8].

Citra (image) adalah ko mbinasi antara titik, garis, bidang dan warna untuk menciptakan suatu imitasi dari suatu objek, biasanya objek fisik atau manusia. Citra bisa berwujud gambar (picture) dua dimensi seperti lukisan, foto, dan yang berwujud tiga dimensi seperti, patung[2]. Adapun format file gambar adalah :

a) Bit map (BMP)

1) Merupakan format citra yang baku dilingkungan sistem Microsoft Windows dan IBM OS/ 2 .

2) Kualitas BMP lebih baik dan dengan ukuran yang lebih baik dari format JPG/ JPEG dan GIF.

3) Format file Bitmap versi baru dari Microsoft Windows, setiap berkas/file terdiri dari: header file, header bitmap, informasi palet, dan data bit map.

b) Joint Photographic Experts Group (JPEG)

1) Dikembangkan oleh para ahli fotografi untuk mendapatkan gambar yang berukuran rasional tapi tetap menyimpan persepsi gambar yang baik.

2) Bersifat lossy dengan tingkat lossness yang dapat diatur.

3) Bagus untuk mengkompresi foto-foto natural tetapi kurang cocok untuk computer-generated images (CGI).

c) Portable Graphics Network (PNG)

1) PNG digunakan di internet dan merupakan format "pengganti" GIF, setelah GIF terkena patent LZW yang dilakukan oleh Unisys

2) Diprakarsai oleh Thomas Boutell dari PNG Development Group, dan versi finalnya di-release pada 1 Oktober 1996.

3) Memiliki kedalaman warna 48-bit.

\section{B. Steganografi}

Steganografi (steganography) adalah ilmu dan seni menyembunyikan pesan rahasia (hiding message) sedemikian sehingga keberadaan pesan tidak terdeteksi oleh indera manusia[9]. Steganorafi berasal dari Bahasa Yunani yang berarti "tulisan tersembunyi" (covered writing). Steganografi membutuhkan wadah penampung dan data rahasia yang akan disembunyikan [10].
1. Algorit ma Pixel Value Differencing (PVD)

Berikut adalah aturan-aturan persamaan algorit ma Pixel Value Differencing (PVD):

$\left(P_{(i, x)}+[m / 2], P_{(i, y)}-[m / 2]\right)$,

Jika $P_{(i, x)} \geq P_{(i, y)}$ dan $\mathrm{d}_{\mathrm{i}}>\mathrm{d}_{\mathrm{i}}$; $\left(P_{(i, x)}-[\mathrm{m} / 2], P_{(i, y)}+[\mathrm{m} / 2]\right)$,

$\left(P_{(i, x)}^{\prime},\left(P_{(i, y)}^{\prime}\right)=\right.$ Jika $P_{(i, x)}<P_{(i, y)}$ dan $\mathrm{d}_{\mathrm{i}}^{\prime}>\mathrm{d}_{\mathrm{i}}$; $\left(P_{(i, x)}-[m / 2], P_{(i, y)}+[m / 2]\right)$,

Jika $P_{(i, x)} \geq P_{(i, y)}$ dan $\mathrm{d}_{\mathrm{i}} \leq \mathrm{d}_{\mathrm{i}}$; $\left(P_{(i, x)}+[\mathrm{m} / 2], P_{(i, y)}-[\mathrm{m} / 2]\right)$, Jika $P_{(i, x)}<P_{(i, y)}$ dan $\mathrm{d}_{\mathrm{i}} \leq \mathrm{d}_{\mathrm{i}}$;

Algorit ma Penyisipan Pesan
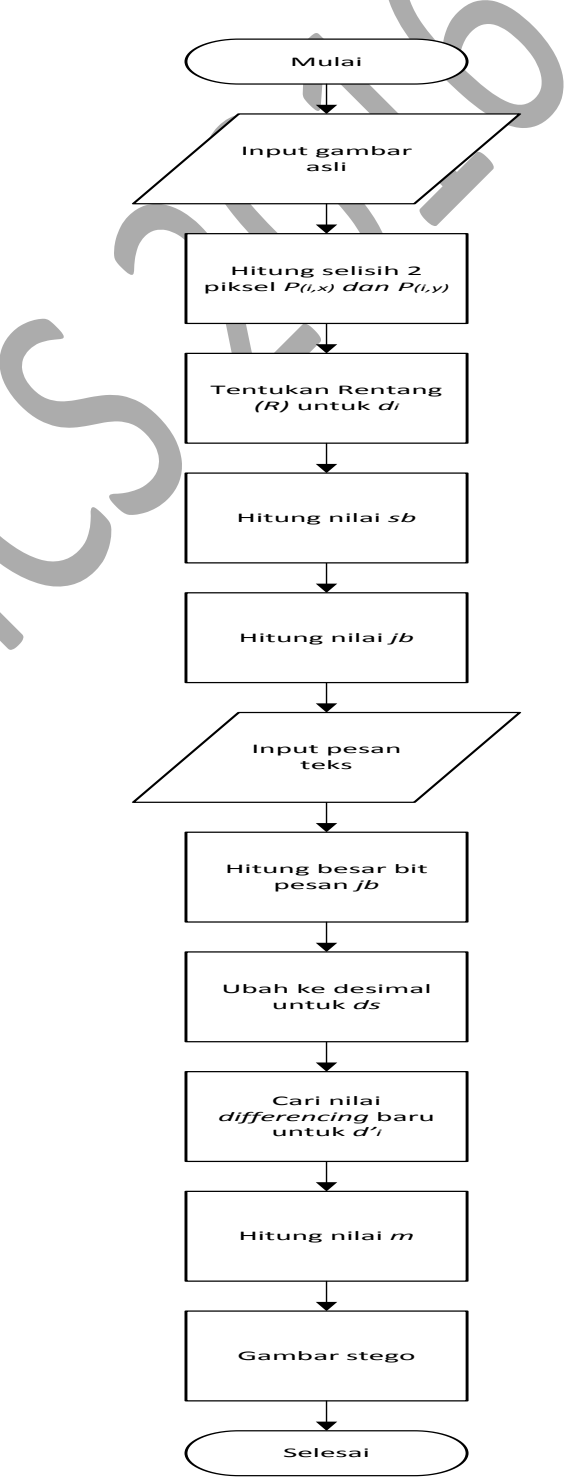

Gambar 1. Flowchart Penyisipan 
Algorit ma Ekstraksi Pesan

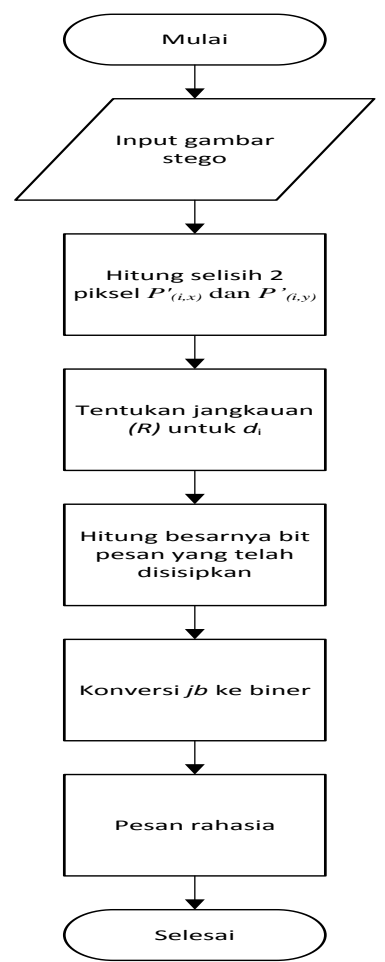

Gambar 2. Fowchart Ekstraksi

2. Peak Signal to Noise Ratio (PNSR) dan Mean Square Error (MSE)

PSNR digunakan untuk menentukan kualitas gambar setelah disisipi pesan. Gambar stego dibandingkan dengan gambar asli untuk menentukan kualitas gambar. Semakin besar nilai PSNR berarti penyisipan pesan ke dalam gambar as li tidak menyebabkan penurunan kualitas gambar stego. Sebaliknya jika nilai PSNR semakin kecil maka pada gambar stego akan terjadi penurunan kualitas gambar.

Nilai PSNR biasanya mempunyai rentang nilai antara $20 \mathrm{~dB}$ sampai dengan $60 \mathrm{~dB}$. Tabel 1 memperlihatkan nilai PSNR beserta penjelasannya.

TABEL 1. NHLAIPSNR

\begin{tabular}{|c|l|}
\hline Rasio (dB) & \multicolumn{1}{c|}{ Kualitas Gambar } \\
\hline $60 \mathrm{~dB}$ & Excellent, tanpa derau \\
\hline $50 \mathrm{~dB}$ & $\begin{array}{l}\text { Good, terdapat banyak derau tapi kualit as citra } \\
\text { masih bagus }\end{array}$ \\
\hline $40 \mathrm{~dB}$ & $\begin{array}{l}\text { Reasonable, terdapat but iran halus seperti salju } \\
\text { dan beberapa det ail citra hilang }\end{array}$ \\
\hline $30 \mathrm{~dB}$ & Poor, terdapat banyak derau pada citra \\
\hline $20 \mathrm{~dB}$ & Unusable \\
\hline
\end{tabular}

Berikut adalah sebuah tabel jangkauan yang digunakan untuk menentukan banyaknya bit yang akan disisipkan:
TABEL 2 BIT YANG DAPAT DISISIPKAN PADA DAERAH RENT ANG

\begin{tabular}{|l|c|c|c|c|c|c|}
\hline$R$ (Rentang) & 1 & 2 & 3 & 4 & 5 & 6 \\
\hline$b b$ (batas bawah) & 0 & 8 & 16 & 32 & 64 & 128 \\
\hline$b a$ (batas at as) & 7 & 15 & 31 & 63 & 127 & 255 \\
\hline$j b$ (jumlah bit) & 3 & 3 & 4 & 5 & 6 & 7 \\
\hline
\end{tabular}

Pada penelitian ini, PSNR digunakan untuk mengetahui perbandingan kualitas gambar sebelum dan sesudah disisipkan pesan. Untuk menentukan PSNR, terlebih dahulu harus ditentukan nilai ratarata kuadrat dari MSE (Mean Square Error). Perhitungan MSE adalah sebagai berikut:

$$
\mathrm{MSE}=\frac{1}{M N} \sum_{y-1}^{M} \sum_{x-1}^{N}[I(x, y)-J(x, y)]
$$

Keterangan:

MSE : Nilai MSE dari gambar steganografi $\mathrm{M}$ : panjang gambar stego (dalam piksel) $\mathrm{N}$ : lebar gambar stego (dalam piksel) $\mathrm{I}(\mathrm{x}, \mathrm{y})$ : nilai piksel dari ga mbar asli $\mathrm{J}(\mathrm{x}, \mathrm{y})$ : nilai piksel dari ga mbar stego

Sementara nilai PSNR dihitung dari kuadrat nilai maksimu m sinyal dibagi dengan MSE.

$$
\text { PSNR }=10 \times \log _{10}\left(\frac{M A X i}{M S E}\right)
$$

Keterangan:

PSNR : nilai PSNR gambar (dalam dB)

MAXi : nilai maksimu m piksel gambar MSE : nilai MSE

\section{PERANCANGAN SISTEM}

Metode yang digunakan dalam perancangan sistem yaitu flowchart dan storyboard yang menggambarkan tentang proses yang terjadi pada sistem yaitu proses masuk (login), penyisipan pesan (embedding), ubah password (update password), dan ekstrak pesan (ekstract).

\section{A. Flowchart Gambaran Umum Aplikasi}




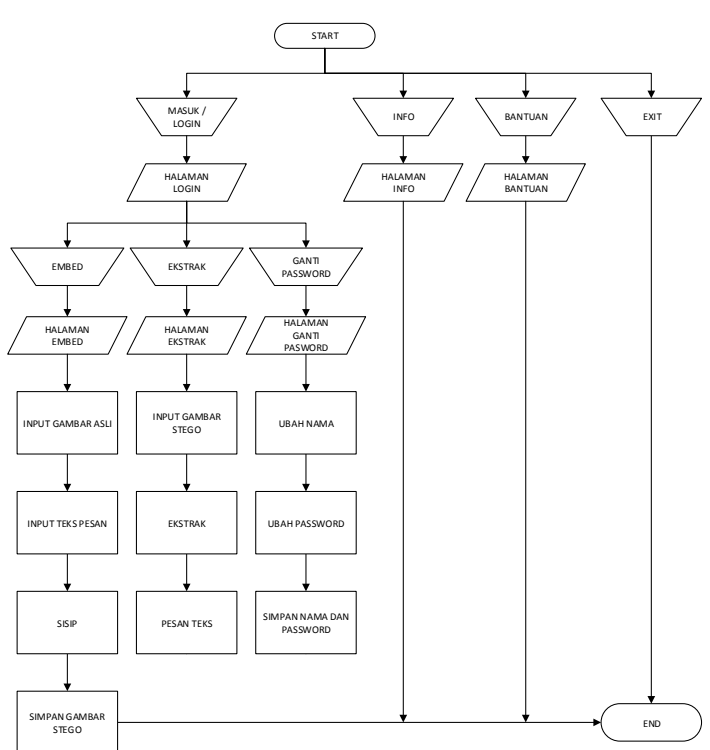

Gambar 3. Flowchart Gambaran Umum Aplikasi

\section{B. Storyboard Aplikasi}

TABEL 3 STORYBOARD APLIKASI ANDROID

\begin{tabular}{|c|c|c|c|}
\hline No & Nama & Desain & Ke terangan \\
\hline 1 & $\begin{array}{l}\text { Splash } \\
\text { Screen }\end{array}$ & & $\begin{array}{l}\text { - Halaman ini menampilkan } \\
\text { Logo aplikasi sebagai } \\
\text { branding aplikasi. } \\
\text { - Durasi 3-5 detik. }\end{array}$ \\
\hline 2 & $\begin{array}{c}\text { Halaman } \\
\text { Awal }\end{array}$ & $\begin{array}{c}10060 \\
\text { stronvockN }\end{array}$ & $\begin{array}{l}\text { - Pada halaman awal terdapat } \\
\text { Logo aplikasi di tengah, } \\
\text { tombol Mulai di bawah, } \\
\text { tombol (i) dan tombol (?) } \\
\text { dipojok kanan atas. } \\
\text { - Tombol Mulai untuk } \\
\text { menuju ke halaman Login } \\
\text { yang digunakan untuk } \\
\text { menginput nama dan } \\
\text { password pengguna. } \\
\text { - Tombol(i) untuk menuju ke } \\
\text { halaman Info yang } \\
\text { menampilkan } \\
\text { informasi/versi dari } \\
\text { aplikasi. } \\
\text { Tombol (?) untuk menuju } \\
\text { ke halaman Bantuan yang } \\
\text { menampilkan isi petunjuk } \\
\text { penggunaan aplikasi. }\end{array}$ \\
\hline 3 & $\begin{array}{c}\text { Halaman } \\
\text { Info }\end{array}$ & $\begin{array}{l}\text { smowooguri } \\
\text { v.s. }\end{array}$ & $\begin{array}{l}\text { - Pada pojok kiri atas terdapat } \\
\text { judul halaman. } \\
\text { - Halaman ini menampilkan } \\
\text { versi dari aplikasi. }\end{array}$ \\
\hline 4 & $\begin{array}{l}\text { Halaman } \\
\text { Bantuan }\end{array}$ & 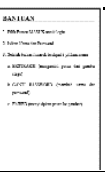 & $\begin{array}{l}\text { - Pada pojok kiri atas terdapat } \\
\text { judul halaman. } \\
\text { - Halaman ini berisitentang } \\
\text { petunjuk penggunaan } \\
\text { aplikasi. }\end{array}$ \\
\hline 5 & $\begin{array}{c}\text { Halaman } \\
\text { Login }\end{array}$ & thax & $\begin{array}{l}\text { - Pada pojok kiri atas terdapat } \\
\text { judul halaman. } \\
\text { - Dibagian tengah terdapat } \\
\text { Nama dan Pass word. } \\
\text { - Dibagian bawah terdapat } \\
\text { tombol Masuk. }\end{array}$ \\
\hline
\end{tabular}

\begin{tabular}{|c|c|c|c|}
\hline & & & $\begin{array}{l}\text { - Nama digunakan untuk } \\
\text { menginput nama pengguna. } \\
\text { - Password digunakan untuk } \\
\text { menginput password } \\
\text { pengguna. } \\
\text { - Tombol Masuk untuk } \\
\text { memproses akun pengguna } \\
\text { menuju ke halaman Menu. }\end{array}$ \\
\hline 6 & $\begin{array}{l}\text { Halaman } \\
\text { Menu }\end{array}$ & 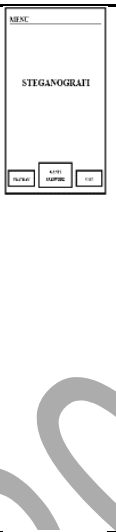 & $\begin{array}{l}\text { - Pada pojok kiri atas terdapat } \\
\text { judul halaman. } \\
\text { - Dibagian tengah terdapat } \\
\text { Logo aplikasi. } \\
\text { - Dibagian bawah terdapat } \\
\text { tombol Ekstrak, tombol } \\
\text { Ganti Pass word dan } \\
\text { tombol Sisip. } \\
\text { - Tombol Ekstrak unt uk } \\
\text { menuju ke halaman } \\
\text { Ekstrak. } \\
\text { - Tombol Ganti Password } \\
\text { untuk menuju ke halaman } \\
\text { Ganti Password. } \\
\text { - TombolSisip unt uk ke } \\
\text { halaman Sisip. }\end{array}$ \\
\hline 7 & $\begin{array}{c}\text { Halaman } \\
\text { Ganti } \\
\text { Password }\end{array}$ & 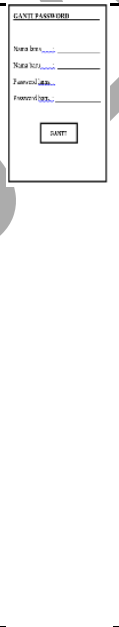 & $\begin{array}{l}\text { - Pada pojok kiri atas terdapat } \\
\text { judul halaman. } \\
\text { - Dibagian tengah terdapat } \\
\text { Nama lama, Nama baru, } \\
\text { Pass word lama, Password } \\
\text { baru dan tombol Ganti. } \\
\text { - Nama lama merupakan } \\
\text { nama dari pengguna awal. } \\
\text { - Nama baru digunakan } \\
\text { untuk nama pengguna baru. } \\
\text { - Pass word lama merupakan } \\
\text { password dari pengguna } \\
\text { awal. } \\
\text { - Password baru digunakan } \\
\text { untuk password pengguna } \\
\text { baru. } \\
\text { - Tombol Ganti untuk } \\
\text { memproses/ mengupdate } \\
\text { pengguna baru. }\end{array}$ \\
\hline 8 & $\begin{array}{l}\text { Halaman } \\
\text { Sisip }\end{array}$ & 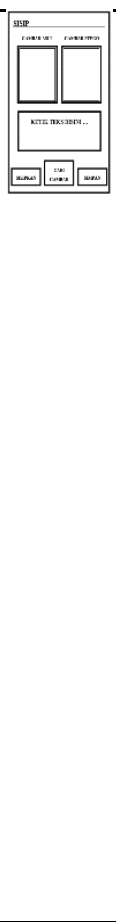 & $\begin{array}{l}\text { - Pada pojok kiri atas terdapat } \\
\text { judul halaman. } \\
\text { - Dibagian tengah terdapat } \\
\text { kotak Gambar asli, kotak } \\
\text { Gambarstego dan kotak } \\
\text { Pesan. } \\
\text { - Dibagian bawah terdapat } \\
\text { tombol Sisip, tombol Cari } \\
\text { Gambar dan tombol } \\
\text { Simpan. } \\
\text { - Kotak Gambar asli } \\
\text { menampilkan gambar asli } \\
\text { yang akan digunakan untuk } \\
\text { menyisipkan pesan. } \\
\text { - Kotak Gambar stego } \\
\text { menampilkan gambar stego } \\
\text { hasil dari penyisipan pesan. } \\
\text { - Kotak Pesan digunakan } \\
\text { untuk mengisi pesan teks } \\
\text { yang akan disisipkan ke } \\
\text { gambar asli. } \\
\text { TombolSisipkan } \\
\text { digunakan unt uk } \\
\text { memproses penyisipan } \\
\text { pesan ke dalam gambar asli. } \\
\text { - TombolCari Gambar } \\
\text { digunakan unt uk mencari } \\
\text { gambar asli dari }\end{array}$ \\
\hline
\end{tabular}




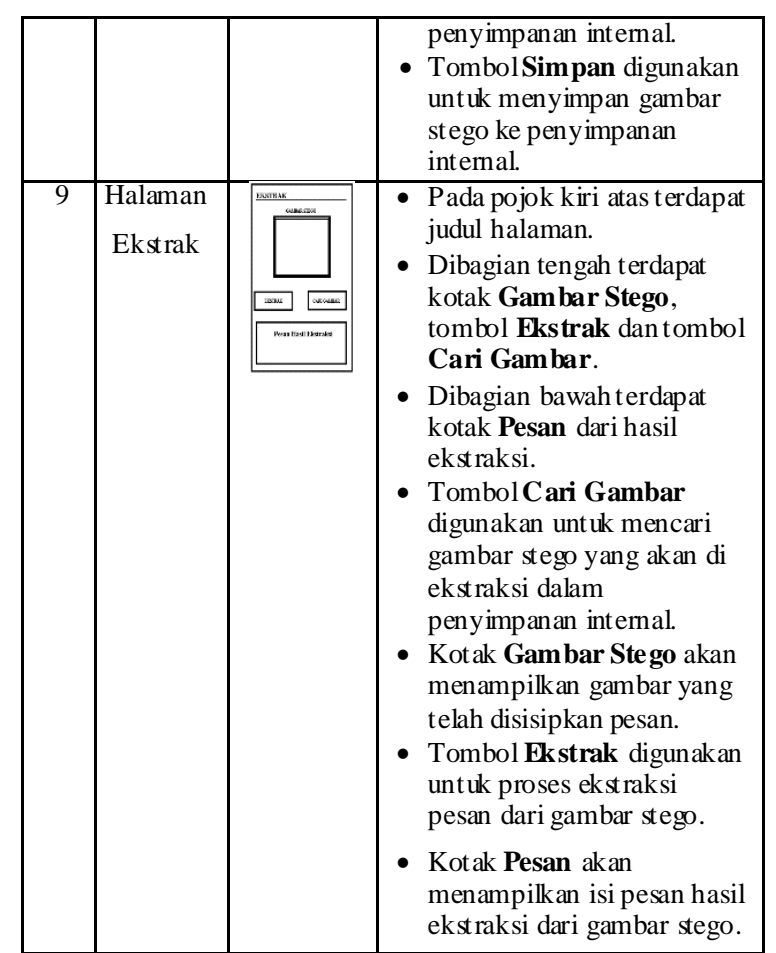

TABEL 4. STORYBOARD APLIKASI MATLAB

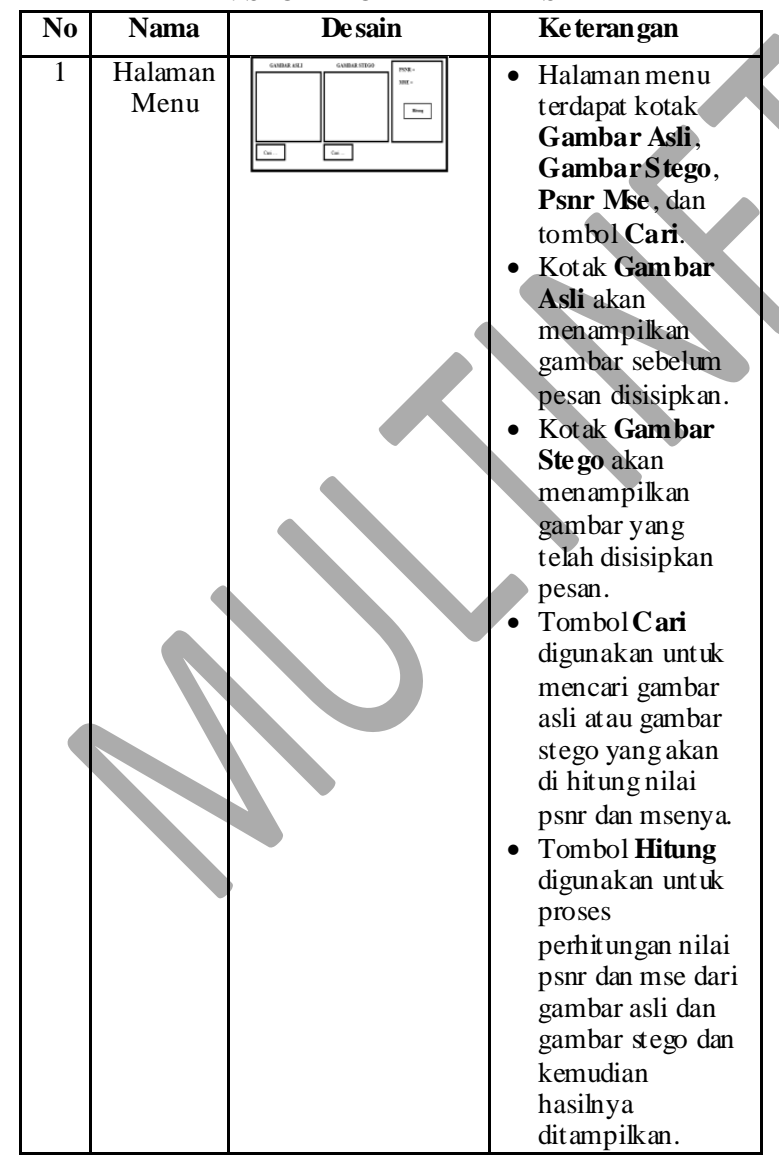

\section{IMPLEMENTASI DAN PENGUJIAN}

Pengujian sistem ini dilakukan dengan pendekatan Desain test case, yaitu dengan menguji aplikasi dengan mencari fungsi-fungsi yang salah, kesalahan desain interface, kesalahan struktur berkas atau akses eksternal. Black-box berfokus pada persyarakatan fungsional perangkat lunak, sehingga mendapatkan serangkaian kondisi input yang seluruhnya menggunakan syarat fungsional pada suatu program (MSE PSNR).

\section{A. Pengujian Aplikasi}

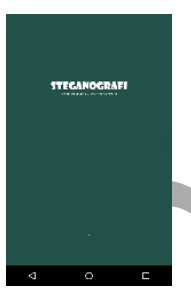

Gambar 4. Halaman Splash Screen

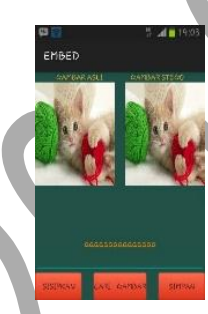

Gambar 5. Proses Penyisipan

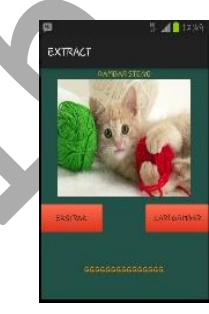

Gambar 6. Proses Ekstraksi

\section{B. Pengujian Gambar}

Pada penelitian ini terdapat enam buah gambar dengan beberapa tipe dan ukuran yang digunakan

TABEL 5. GAMBAR YANG AKAN DI UJI DENGAN UKURANPIKSEL BERVARIASI

\begin{tabular}{|l|l|l|l|l|}
\hline $\begin{array}{l}\text { Nama } \\
\text { Gambar }\end{array}$ & Gambar & $\begin{array}{l}\text { Ukuran } \\
\text { Gambar } \\
\text { (piksel) }\end{array}$ & $\begin{array}{l}\text { Tipe } \\
\text { Gambar }\end{array}$ & $\begin{array}{l}\text { Ukuran } \\
\text { gambar } \\
(\mathrm{KB})\end{array}$ \\
\hline Bunga & $128 \times 128$ & PNG & 42.7 \\
\hline Ferrari & & $128 \times 128$ & JPG & 10.7 \\
\hline Singa & & $128 \times 128$ & BMP & 48.0 \\
\hline
\end{tabular}

\section{Pengujian Nilai MSE dan PSNR}

Algoritma MSE dan PSNR dibuat dengan menggunakan bahasa pemrograman Matlab. Matlab merupakan bahasa pemrograman yang sangat baik untuk mengolah gambar karena dilengkapi fungsi-fungsi yang memudahkan pemakaiannya. Berikut ini merupakan program yang digunakan untuk mengetahui nilai MSE dan PSNR dari setiap gambar yang sebelum dan sesudah disisipkan pesan 


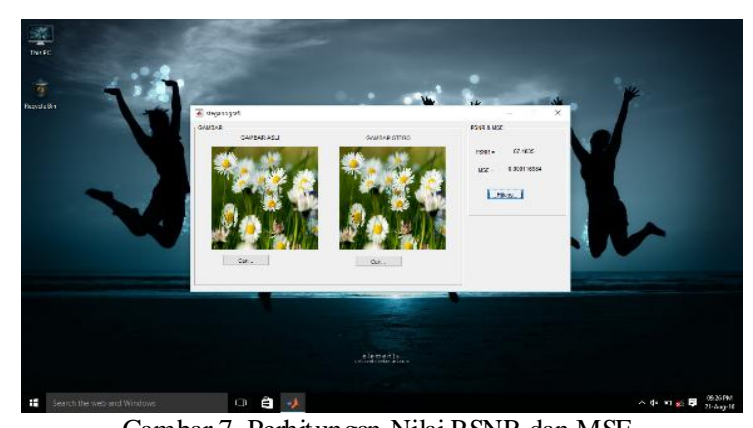

Gambar 7. Perhit ungan Nilai PSNR dan MSE

TABEL 6. GAMBAR YANG AKAN DI UJI DENGAN UKURANPIKSEL SAMA

\begin{tabular}{|c|c|c|c|c|}
\hline $\begin{array}{l}\text { Nama } \\
\text { Gambar }\end{array}$ & Gambar & $\begin{array}{l}\text { Ukuran } \\
\text { Gambar } \\
\text { (piksel) }\end{array}$ & $\begin{array}{l}\text { Tipe } \\
\text { Gambar }\end{array}$ & $\begin{array}{l}\text { Ukuran } \\
\text { gambar } \\
\text { (KB) }\end{array}$ \\
\hline Bunga & & $512 \times 512$ & PNG & 734 \\
\hline Kucing & & $912 \times 800$ & BMP & 2000 \\
\hline Singa & & $128 \times 116$ & JPG & 10.9 \\
\hline
\end{tabular}

\section{Hasil Pengujian}

Hasil pengujian nilai MSE pada gambar dengan ukuran piksel dan tipe yang berbeda dapat dilihat pada Tabel 7.

TABEL 7. HASIL PENGUJIAN GAMBARDALAM

\begin{tabular}{|c|c|c|c|}
\hline \multirow{2}{*}{$\begin{array}{c}\text { Jumlah } \\
\text { karak ter } \\
\text { yang } \\
\text { disisipkan }\end{array}$} & \multicolumn{3}{|c|}{ NILAI MSE (db) } \\
\cline { 2 - 4 } & Bunga.png & Ku cing.bmp & Singa.jpg \\
\hline 15 & 0.000116 & 0.000053 & 1.20842 \\
\hline 30 & 0.000389 & 0.000132 & 1.23682 \\
\hline 50 & 0.000729 & 0.000184 & 1.32368 \\
\hline 70 & 0.001118 & 0.000291 & 1.24524 \\
\hline 130 & 0.002301 & 0.000947 & 1.29443 \\
\hline 150 & 0.003281 & 0.000891 & 1.30758 \\
\hline 230 & 0.003607 & 0.00163 & 1.42143 \\
\hline 300 & 0.007386 & 0.002214 & 1.45317 \\
\hline 400 & 0.010397 & 0.00311 & 1.55859 \\
\hline 500 & 0.013989 & 0.004204 & 1.62022 \\
\hline
\end{tabular}

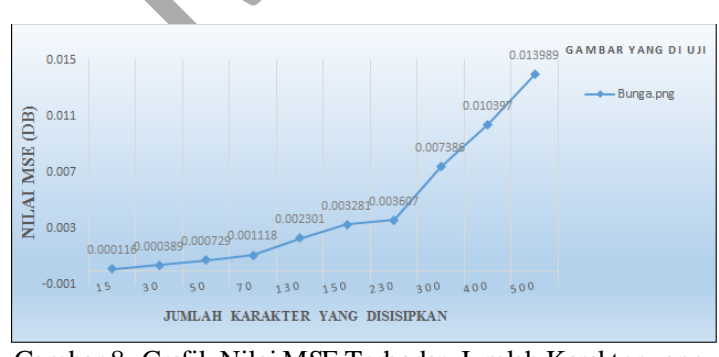

Gambar 8. Grafik Nilai MSE Terhadap Jumlah Karakter yang disisipkan pada Gambar Bunga.png

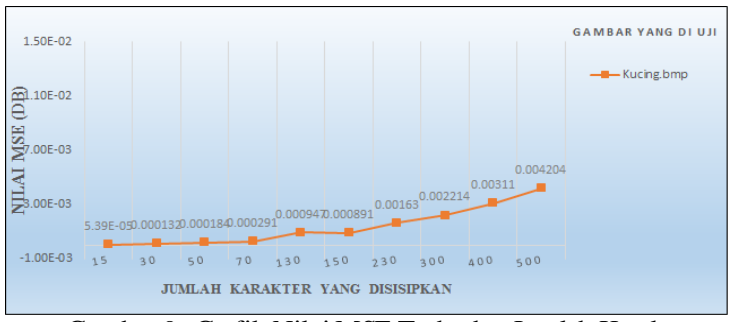

Gambar 9. Grafik Nilai MSE Terhadap Jumlah Karakter yang disisipkan pada Gambar Kucing.bmp

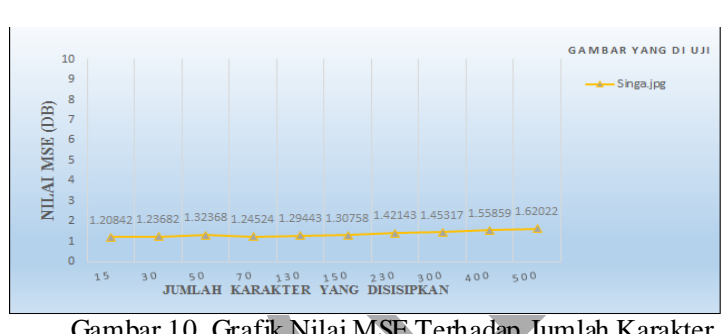

Gambar 10. Grafik Nilai MSE Terhadap Jumlah Karakter yang disisipkan pada Gambar Singa.jpg

Hasil pengujian nilai PSNR pada gambar dengan ukuran piksel dan tipe yang berbeda dapat dilihat pada Tabel 8.

TABEL 8. HASIL PENGUJIAN GAMBAR DALAM NILAI

\begin{tabular}{|c|c|c|c|}
\hline \multirow{2}{*}{$\begin{array}{c}\text { Jumlah } \\
\text { karakter } \\
\text { yang } \\
\text { disisipkan }\end{array}$} & \multicolumn{3}{|c|}{ PSNR (DB) } \\
\cline { 2 - 4 } & Bunga.png & Kucing.bmp & Singa.jpg \\
\hline 15 & 87.4835 & 90.848 & 47.3426 \\
\hline 30 & 82.2642 & 86.9579 & 47.2417 \\
\hline 50 & 79.5323 & 85.503 & 46.947 \\
\hline 70 & 77.6766 & 83.5187 & 47.2123 \\
\hline 130 & 74.5446 & 78.4009 & 47.044 \\
\hline 150 & 73.0035 & 78.6621 & 47.0001 \\
\hline 230 & 72.5928 & 76.0414 & 46.6376 \\
\hline 300 & 69.4804 & 74.7121 & 46.5416 \\
\hline 400 & 67.9955 & 73.236 & 46.2375 \\
\hline 500 & 66.7067 & 71.9276 & 46.0691 \\
\hline
\end{tabular}

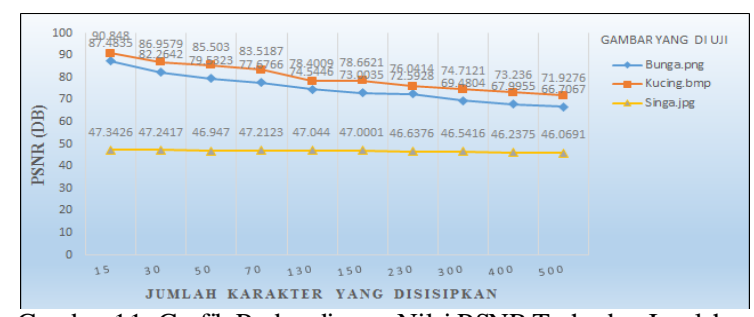

Gambar 11. Grafik Perbandingan Nilai PSNR Terhadap Jumlah Karakter yang disisipkan pada Gambar Bunga.png, Kucing.bmp dan Singa.jpg

Hasil pengujian nilai MSE pada ketiga gambar dengan ukuran piksel yang sama dapat dilihat pada Tabel 9. 
TABEL 9. HASIL PENGUJIAN GAMBAR DALAM NILAI MSE (DB)

\begin{tabular}{|c|c|c|c|}
\hline \multirow{2}{*}{$\begin{array}{c}\text { Jumlah } \\
\text { karakter } \\
\begin{array}{c}\text { yang } \\
\text { disisipkan }\end{array}\end{array}$} & \multicolumn{3}{|c|}{ NILAI MSE (db) } \\
\cline { 2 - 4 } & Bunga.png & Fe rrari.jpg & Singa.bmp \\
\hline 15 & 0.003031 & 6.8701 & 0.00921 \\
\hline 30 & 0.006327 & 6.927 & 0.01747 \\
\hline 50 & 0.013590 & 6.9164 & 0.03108 \\
\hline 70 & 0.379171 & 7.0687 & 0.04317 \\
\hline 130 & 0.39679 & 6.9039 & 0.08593 \\
\hline 150 & 0.060852 & 7.6477 & 0.10424 \\
\hline 230 & 0.069925 & 6.99259 & 0.16278 \\
\hline 300 & 0.128906 & 6.999 & 0.22363 \\
\hline 400 & 0.139201 & 7.0807 & 0.28945 \\
\hline 500 & 0.223897 & 7.13499 & 0.52794 \\
\hline & & & \\
\hline
\end{tabular}

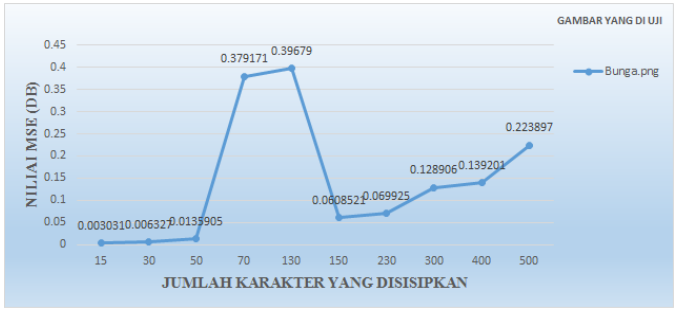

Gambar 12. Grafik Nilai MSE Terhadap Jumlah Karakter yang disisipkan pada Gambar Bunga.png

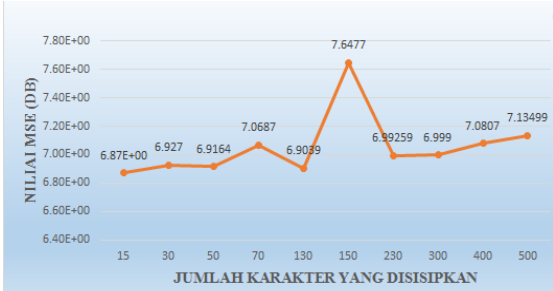

Gambar 13. Grafik Nilai MSE Terhadap Jumlah Karakter yang disisipkan pada Gambar Ferrari.jpg

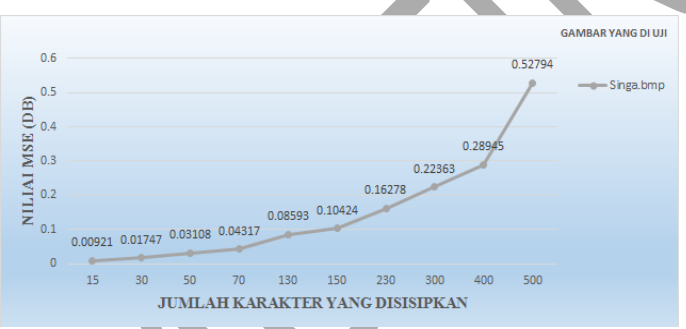

Gambar 14. Grafik Nilai MSE Terhadap Jumlah Karakter yang disisipkan pada Gambar Singa.bmp

Hasil pengujian nilai PSNR pada ketiga gambar dengan ukuran piksel yang sama:

TABEL 10. HASIL PENGUJIAN GAMBAR DALAM NILAI PSNR (DB)

\begin{tabular}{|c|c|c|c|}
\hline \multirow{2}{*}{$\begin{array}{c}\text { Jumlah } \\
\text { karakter } \\
\text { yang } \\
\text { disisipkan }\end{array}$} & \multicolumn{3}{|c|}{ NILAI PSNR (db) } \\
\cline { 2 - 4 } & Bunga.png & Ferrari.jpg & Singa.bmp \\
\hline 15 & 73.3483 & 39.7951 & 68.5192 \\
\hline 30 & 70.1526 & 39.7593 & 65.7403 \\
\hline 50 & 66.834 & 39.766 & 63.239 \\
\hline 70 & 52.3765 & 39.6714 & 61.8128 \\
\hline 130 & 52.1792 & 39.7738 & 58.823 \\
\hline 150 & 60.322 & 39.3295 & 57.9841 \\
\hline 230 & 59.7184 & 39.7184 & 56.0488 \\
\hline
\end{tabular}

\begin{tabular}{|l|c|c|c|}
\hline 300 & 57.0621 & 39.7144 & 54.6694 \\
\hline 400 & 56.7284 & 39.664 & 53.5488 \\
\hline 500 & 54.6643 & 39.6309 & 50.939 \\
\hline
\end{tabular}

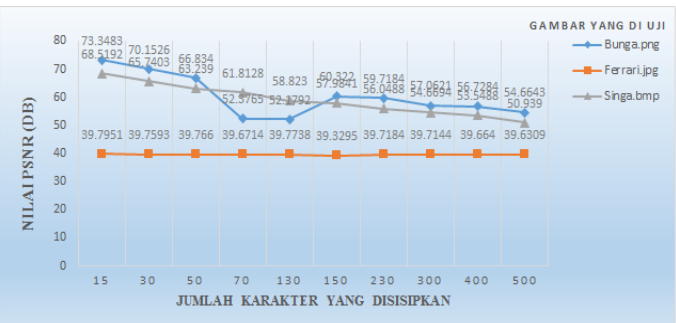

Gambar 15. Grafik Perbandingan Nilai PSNR T erhadap Jumlah Karakter yang disisipkan pada Gambar Bunga.png, Ferrari.jpg dan Singa.bmp

\section{E. Pengujian Stress Testing}

Stress testing adalah salah satu jenis pengujian sistem (system testing). Pengujian ini bertujuan untuk melihat apakah perangkat lunak secara keseluruhan mampu menangani kebutuhan sumberdaya yang tidak normal (mencakup kuantitas, frekuensi, maupun volume). Apakah data dalam jumlah sangat besar, dengan frekuensi sangat tinggi, serta volume yang sangat besar mengakibatkan performa atau bahkan fungsionalitas perangkat lunak terganggu atau tidak. Jadi, meskipun perangkat lunak anda sudah berjalan baik di setiap fiturnya, pastikan juga setiap perangkat lunak tetap bekerja dengan maksimal saat diberi 'beban berat'. Jangan hanya menguji dengan data uji yang terbatas [1].

Stress test dilakukan secara bertahap yaitu pertama dengan test kecil dan dilanjutkan dengan maksimal yang bisa ditangani oleh aplikasi, ini penting karena kita harus mengetahui seberapa besar aplikasi dalam menangani beban.

TABEL 11 HASILPENGUJIAN ST RESS TEST ING

\begin{tabular}{|c|c|c|c|c|c|}
\hline $\begin{array}{c}\text { Nama } \\
\text { Gambar }\end{array}$ & Gambar & $\begin{array}{l}\text { Ukuran } \\
\text { (piksel) }\end{array}$ & Tipe & $\begin{array}{l}\text { Ukur } \\
\text { an } \\
\text { (KB) }\end{array}$ & $\begin{array}{c}\text { Maks } \\
\text { pesan } \\
\text { (karakter) }\end{array}$ \\
\hline Bunga & & $\begin{array}{c}512 \times \\
512\end{array}$ & PNG & 734 & 526484 \\
\hline Kucing & & $\begin{array}{c}912 \mathrm{x} \\
800\end{array}$ & BMP & 2080 & 1576067 \\
\hline Singa & & $\begin{array}{c}128 \mathrm{x} \\
116\end{array}$ & JPG & 10.9 & 8093 \\
\hline Bunga & & $\begin{array}{c}128 \mathrm{x} \\
128\end{array}$ & $\overline{\mathrm{PNG}}$ & 42.7 & 32178 \\
\hline Ferrari & & $\begin{array}{c}128 \mathrm{x} \\
128\end{array}$ & JPG & $\begin{array}{l}10.7 \\
\end{array}$ & 8992 \\
\hline
\end{tabular}




\begin{tabular}{|c|r|c|c|c|c|}
\hline Singa & $\mathrm{S}$ & $128 \mathrm{x}$ & $\mathrm{BMP}$ & 48.0 & 34244 \\
& 128 & & $\mathrm{~KB}$ & \\
& & & & & \\
\hline
\end{tabular}

\section{KESIMPULAN DAN SARAN}

\section{A. Kesimpulan}

1. Aplikasi steganografi dengan metode Pixel Value Differencing (PVD) pada mobile phone berbasis Android ini dapat menyembunyikan informasi dengan melakukan penyisipan pesan dan ekstraksi pesan rahasia.

2. Teknik steganografi dengan metode Pixel Value Differencing (PVD) dapat digunakan pada sebuah gambar dengan 3 tipe berbeda yaitu: .png, .jpg dan .bmp dengan ukuran yang berbeda.

3. Berdasarkan dari hasil analisa penelitian ini dapat disimpulkan bahwa:

a. Aplikasi steganografi yang dibuat dari implementasi algoritma Pixel Value Differencing (PVD) menunjukkan bahwa kualitas terhadap ketiga gambar yang diujikan dengan ukuran dan tipe berbeda masih dalam keadaan baik yaitu berkualitas reasonable sampai dengan excelent, karena PSNR berkisar antara $46.0 \mathrm{db}$ sampai 90.8 $\mathrm{db}$ yaitu menunjukan perubahan kualitas gambar rendah.

b. Pada proses ekstraksi, pesan yang disisisipkan pada gambar dalam aplikasi steganografi ini, dapat diekstrak kembali dengan baik yaitu pesan yang disisipkan sebelum proses penyisipan dan setelah proses ekstraksi sama tanpa ada perubahan atau error yang menyebabkan isi pesan tidak dapat dike mbalikan.

c. Hasil pengujian nilai MSE dan PSNR terhadap gambar yang dihasilkan dari aplikasi steganografi in i pun menunjukkan nilai yang cukup baik bergantung pada tipe gambar yang digunakan dan besarnya jumlah karakter yang disisipkan pada gambar tersebut. Hasil pengujian pada gambar dengan ukuran berbeda, gambar Kucing.bmp memperoleh nilai desibel yang lebih baik antara 71.0 sampai 90.0 dibandingkan dengan gambar Bunga.png antara 66.0 sampai 87.0 dan gambar Singa.jpg antara 46.0 sampai 47.0. Ini menunjukkan bahwa diantara gambar Bunga.png dan gambar Singa.jpg, gambar Kucing.bmp lebih baik untuk penyisipan pesan rahasia dengan perubahan kualitas gambar sangat kecil karena memperoleh nilai PSNR yang tinggi, semakin besar nilai PSNR semakin kecil perubahan kualitas gambar.

\section{B. Saran}

Aplikasi ini bisa dikembangkan lagi untuk penelitian selanjutnya terutama untuk mengirimkan dan menerima pesan gambar hasil steganografi.

1. Untuk lebih mengamankan data/informasi yang sangat rahasia dapat menggunakan penggabungan antara teknik steganografi dan kriptografi.

2. Pengembangan selanjutnya dapat menggunakan algoritma steganografi lain yang dapat mengkompresi sebuah gambar dengan input dan output gambar yang mempunyai format lebih bervarian lagi.

3. Aplikasi ini hanya dapat menyisipkan sebuah pesan, sehingga untuk penelitian selanjutnya dapat menggunakan file dengan format/tipe lainnya *.doc, *.ppt, *.pdf dan sebagainya

\section{REFERENSI}

Jayadi, "Kompasiana," 5 Januari 2011. [Online]. Available:http://www.kompasiana.com/highspeed/stresstest. [Accessed 1 Agustus 2016].

[2] R. Munir, "Steganografi dan Watermarking," Bahan Kuliah ke-7, 2004.

[3] Mehdi Hussain; Ainuddin Wahid Abdul Wahab; Nor Badrul Anuar; Rosli Salleh; Rafidah Md Noor, 2015, "Pixel value differencing steganography techniques: Analysis and open challenge", IEEE International Conference on Consumer Electronics - Taiwan, Pages: $21-22$.

[4] Zhenhao Zhu; Tao Zhang; Pengwei Zhu; Baoji Wan; Xiaodan Hou, 2013, "Steganalysis of AE-LSB steganography based on pixel value differencing", Ninth International Conference on Natural Computation (ICNC), Pages: 1449 - 1453.

[5] C. Wu and W. H. T sai, "A steganographic method for images by pixel-value differencing", vol. 24, pp. 1613$1626,2003$.

[6] K. Gulve Avinash; M. S. Joshi, 2012, “A Secured Five Pixel Pair Differencing Algorithm for Compressed Image Steganography", Third International Conference on Computer and Communication Technology, Pages: $278-282$.

[7] Rozali, S. Guritman and H. T. Natalisa, "Perbaikan Dan Evaluasi Kinerja Algoritma Pixel- Value Differencing (PVD)", vol. 09, 2009.

[8] R. Munir, "Pengantar Pengolahan Citra". Bandung, 2004.

[9] W. T. Hsien and S. L. Hui, "A Steganographic Method Based on Pixel-Value Differencing and the Perfect Square Number," Journal of Applied Mathematics, vol. 2013, no. 5, pp. 8, 2013.

[10] M. A. Andriawan, S. and S. J. I. Ismail, "Implementasi Steganografi Pada Citra Digital File Gambar Bitmap (BMP) Menggunakan Java", Bandung: Politeknik Telkom. 